\title{
HYDROCHEMICAL ANALYSIS OF A BASIN UNDER ANTHROPOGENIC INFLUENCE AND EFFECTS IN MANAUS' SHORELINE - CENTRAL AMAZONIA
}

\author{
Bruno Del Rio Calvo \\ Serviço Geológico do Brasil, Laboratório de Análises Minerais, Manaus, AM, Brasil. \\ bruno.calvo@cprm.gov.br \\ Tereza Cristina Souza de Oliveira \\ Universidade Federal do Amazonas, Departamento de Química, Manaus, AM, Brasil. \\ terezacristina@ufam.edu.br
}

\begin{abstract}
Environmental research realized at Educandos basin (Manaus - AM), which includes several dwelling-places and Manaus Free Trade Zone (ZFM), to avail the impact of anthropogenic activity on local streams and potential influences over Rio Negro, at Manaus' shoreline. It was determined $\mathrm{pH}$, E.C., turbidity, temperature, TSS, anions $\left(\mathrm{HCO}_{3}^{-}, \mathrm{NO}_{3}^{-}, \mathrm{F}^{-}\right.$, $\left.\mathrm{Cl}^{-}, \mathrm{SO}_{4}{ }^{2-}\right)$ and dissolved metals $\left(\mathrm{Ni}^{2+}, \mathrm{Pb}^{2+}, \mathrm{Cr}^{3+}, \mathrm{Cu}^{2+}, \mathrm{Fe}^{2+}, \mathrm{V}^{+}, \mathrm{Zn}^{2+}\right.$ e $\left.\mathrm{Al}^{3+}\right)$. Anions were measured by HPLC; metals, by ICP-OES; and remainder parameters by classic methods. All the analyzed parameters were altered at streams because of anthropogenic activity. Results showed Quarenta stream hadn't had altered the quality standards of Rio Negro's water. It was noticed a high degradation on the base level of Cachoeirinha and Mestre Chico streams, in which were found the highest levels of $\mathrm{Cl}^{-}, \mathrm{F}^{-}, \mathrm{SO}^{2-}, \mathrm{E} . \mathrm{C} ., \mathrm{pH}$ e $\mathrm{HCO}_{3}{ }^{-}$. These parameters were higher than those obtained in last decades, indicating an increase in contamination by sewage. Places near ZFM presented high levels of $\mathrm{Ni}^{2+}$ e $\mathrm{Al}^{3+}$, arising from industrial waste. Levels for metals $\mathrm{Pb}^{2+}, \mathrm{Cr}^{3+}, \mathrm{Cu}^{2+}, \mathrm{V}^{+}$were recorded below the permissible limits according to Resolution n.357/2005 - CONAMA in all spots, indicating a possible reduction on the emission of potentially toxic metals.
\end{abstract}

Keywords: Water quality. Surface water stream. Rio Negro.

\section{HIDROQUÍMICA DE BACIA HIDROGRÁFICA SOB INFLUÊNCIA ANTROPOGÊNICA E SEUS EFEITOS NA ORLA DA CIDADE DE MANAUS - AMAZÔNIA CENTRAL}

\begin{abstract}
RESUMO
Estudo ambiental realizado na bacia do Educandos (Manaus-AM), que abrange grande quantidade de residências e o Pólo Industrial de Manaus (PIM), vem avaliar o impacto das atividades antrópicas nos igarapés dessa bacia e potenciais influências ao Rio Negro, na orla de Manaus. Foi determinado o pH, C.E., turbidez, temperatura, SST, ânions $\left(\mathrm{HCO}_{3}\right.$ $\left., \mathrm{NO}_{3}{ }^{-}, \mathrm{F}^{-}, \mathrm{Cl}^{-}, \mathrm{SO}_{4}^{2-}\right)$ e metais $\left(\mathrm{Ni}^{2+}, \mathrm{Pb}^{2+}, \mathrm{Cr}^{3+}, \mathrm{Cu}^{2+}, \mathrm{Fe}^{2+}, \mathrm{V}^{+}, \mathrm{Zn}^{2+}\right.$ e $\left.\mathrm{Al}^{3+}\right)$. Mensurou-se os ânions por CLAE, os metais por ICP-OES e demais parâmetros por métodos clássicos. Constatou-se alteração de todos os parâmetros nos igarapés pela atividade antropogênica. Observou-se que o igarapé do Quarenta não alterou significativamente os padrões de qualidade da água na orla do Rio Negro. Observou-se elevada degradação da foz dos igarapés do Cachoeirinha e Mestre Chico com os mais elevados níveis de $\mathrm{Cl}^{-}, \mathrm{F}^{-}, \mathrm{SO}_{4}^{2-}$, C.E., $\mathrm{pH}$ e $\mathrm{HCO}_{3}{ }^{-}$. Estes parâmetros foram mais altos que em décadas passadas, indicando um aumento de contaminação por esgotos. Locais ao lado do PIM apresentaram altos teores de $\mathrm{Ni}^{2+}$ e $\mathrm{Al}^{3+}$, decorrente da emissão industrial. Os metais de $\mathrm{Pb}^{2+}, \mathrm{Cr}^{3+}, \mathrm{Cu}^{2+}, \mathrm{V}^{+}$ mantiveram-se adequados a legislação $N^{\circ} 357 / 2005$ do CONAMA em todos os pontos de coleta, indicando possível redução da emissão de metais potencialmente tóxicos.
\end{abstract}

Palavras-Chave: Qualidade de águas. Igarapé do Quarenta. Rio Negro.

\section{INTRODUCTION}

Amazonia is worldwide acknowledged by its importance concerning the climatic balance on Earth and biodiversity and, most of all, fresh water reservoirs, being responsible for $15 \%$ of fresh water in the oceans (MOLINIER et al., 1996). Amazon River contributes with $6.660109 \mathrm{~m}^{3} / \mathrm{year}$ of liquid discharge in Atlantic Ocean (FILIZOLA and GUYOT, 2011). Amazon basin comprehends a complex drainage system with

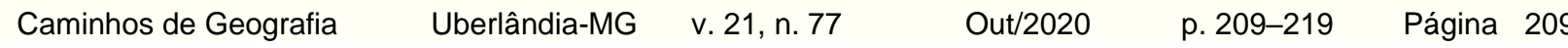


different geomorphologic, physic and chemical characteristics. The persistent occurrence of accidents with negative impacts to aquatic environment, including some happened in Amazonia, must be considered concerning, being it the motivation behind this research.

It is necessary to record the current alteration levels in water quality under the anthropic influence in Amazon environment. There are many interests surrounding the way humans act over ground in Amazonia - installing dams in hydroelectric plants, groundwater usage, ports installation, mineral and industrial exploration, deforestation aiming space for animal husbandry or vegetal extraction, fishing and pisciculture, among other reasons. In this context, Manaus city presents the most impacted places, being the biggest city in Central Amazonia, with an estimated population of 2.14 million inhabitants (IBGE, 2018). Manaus is located on the left side of Rio Negro, in which shorelines occur the urban discharges of Tarumã, São Raimundo, Educandos and Puraquequara hydrographic sub-basins.

Manaus Free Trade Zone motivated a large demographic growth (MACIEL, 2016). Yet, public works (related to infrastructure and sanitation) implemented in the city were not enough, degrading the urban streams (GEOCIDADES, 2002; NORMANDO, 2014). Since 1990's, it is noticed Educandos basin presents spots with advanced deterioration, with notorious alterations in its physical and chemical characteristics, like pH, E.C.(Electrical Conductivity), $\mathrm{NH}_{4}{ }^{+}, \mathrm{COD}$ (Chemical Oxygen Demand), BOD (Biochemical Oxygen Demand), anions $\left(\mathrm{Cl}^{-}, \mathrm{SO}_{4}{ }^{2-}, \mathrm{NO}_{3}{ }^{-}, \mathrm{NO}_{2}-\right)$ and potentially toxic metals $\left(\mathrm{Ni}^{2+}, \mathrm{Cu}^{2+}, \mathrm{Cr}^{3+}, \mathrm{Pb}^{2+}\right.$ and $\left.\mathrm{V}^{+}\right)$ (SAMPAIO and SANTANA, 2000; MACHADO and SANTANA, 2000; NORMANDO, 2014; COSTA et al., 2016; VIANA, 2018). Its contamination is due to continuous emission of sewage and garbage happened in the neighborhood and from industrial waste emitted by ZFM (SILVA; RAMOS; PINTO,1999; GEISSLER, 2003; MELO; SILVA; MIRANDA, 2005; RODRIGUES; SILVA; SILVA, 2009; SILVA, 2010). The sewage in Educandos basin is released into Rio Negro river without treatment.

This research wishes to avail the contamination degree on the Educandos basin's stream, the probable origin of those contaminants (come from industrial emission or sewage), the possible environmental influence from contamination at Educandos to Rio Negro's shoreline and the effects of seasonal variation of pluviometry on the parameters of water quality.

\section{MATERIALS AND METHODS}

Educandos basin is totally located in Manaus's urban area. Its sources are in the neighborhoods of Zumbi and Armando Mendes, its courses are along the margins of Manaus Free Trade Zone (ZFM), and its mouths are located in Rio Negro (GEOCIDADES, 2002), comprehending $48.5 \mathrm{~km}$ in its 33 courses, some of them being the streams Quarenta, Cachoeirinha and Mestre Chico (MACIEL, 2016). Quarenta it's the longest and most studied stream, and in its course drains nearly all Educandos basin tributaries. In Quarenta and Mestre Chico confluence they form Educandos Stream (same name of the basin), a wider stream that flows into Rio Negro.

The city of Manaus presents humid tropical monsoon climate, with medium pluviometry of 2,300 mm year ${ }^{-1}$, heterogeneously distributed in a season of high pluviometry - wet season - (from November to May) and another of dry season (from June to November) (MELO; SILVA; MIRANDA, 2005; MACIEL, 2016). The samples were collected at seventeen different spots, three of them in Educando's sources in an environmental protected area in UFAM campus (S1, S2, S3), eight on streams, being six spots located at Quarenta stream (QS1, QS2, QS3, QS4, QS5 and QS6), one at Mestre Chico stream mouth (MS1), one at Cachoeirinha stream mouth (CS1), and six on Rio Negro: three upstreams (NU1, NU2 and NU3) and three downstreams (ND1, ND2 and ND3) from Educandos mouth (Fig. 1).

The samples were collected on the surface $(0.5 \mathrm{~m})$ on April (wet season) and September (dry season), 2017. Stream sampling (except sources) were conducted from bridges, at the approximate center-of-flow, and river sampling were collected by boat at average $250 \mathrm{~m}$ away from Rio Negro margins (in wet season).

It was used adequate standard techniques for environmental analysis, with analytical methods as calibration, triplication and analysis blank (APHA, 2017). Conductivity and temperature were measured in situ by conductimetry and digital thermometer using Ysi® Ysi 30; $\mathrm{pH}$ was measured by potentiometry using Thermo ${ }^{\circledR}$ Orion 3; turbidity by turbidimetry using $\mathrm{HACH}^{\circledR} 2100 \mathrm{Q} ; \mathrm{HCO}_{3}{ }^{-}$by potentiometric titration using Metrohm ${ }^{\circledR}$ Titrino 848 plus; total suspended solids (TSS) using cellulose ester membranes with $0.45 \mu \mathrm{m}$; anions $\left(\mathrm{F}^{-}, \mathrm{Cl}^{-}, \mathrm{SO}_{4}{ }^{2-}\right.$ and $\left.\mathrm{NO}_{3}{ }^{-}\right)$by liquid chromatography using Dionex ${ }^{\circledR} \mathrm{ICS}-5000$; and cations $\left(\mathrm{Cu}^{2+}, \mathrm{Cr}^{3+}\right.$, $\mathrm{Pb}^{2+}, \mathrm{Fe}^{2+}, \mathrm{Al}^{3+}$ and $\left.\mathrm{V}^{+}\right)$by spectroscopy using PerkinElmer ${ }^{\circledR}$ ICP-OES OPTIMA 8000. Samples were preserved at $4^{\circ} \mathrm{C}$, filtered in situ in $0.45 \mu \mathrm{m}$ membranes (for measuring cations and anions) and $1 \mathrm{~mL} \mathrm{HNO}_{3}$ $1: 1$ was added in $49 \mathrm{~mL}$ sample for preserving metals. 
Figure 1 - Educandos basin - Sampling sites and map of the study area, 2020.

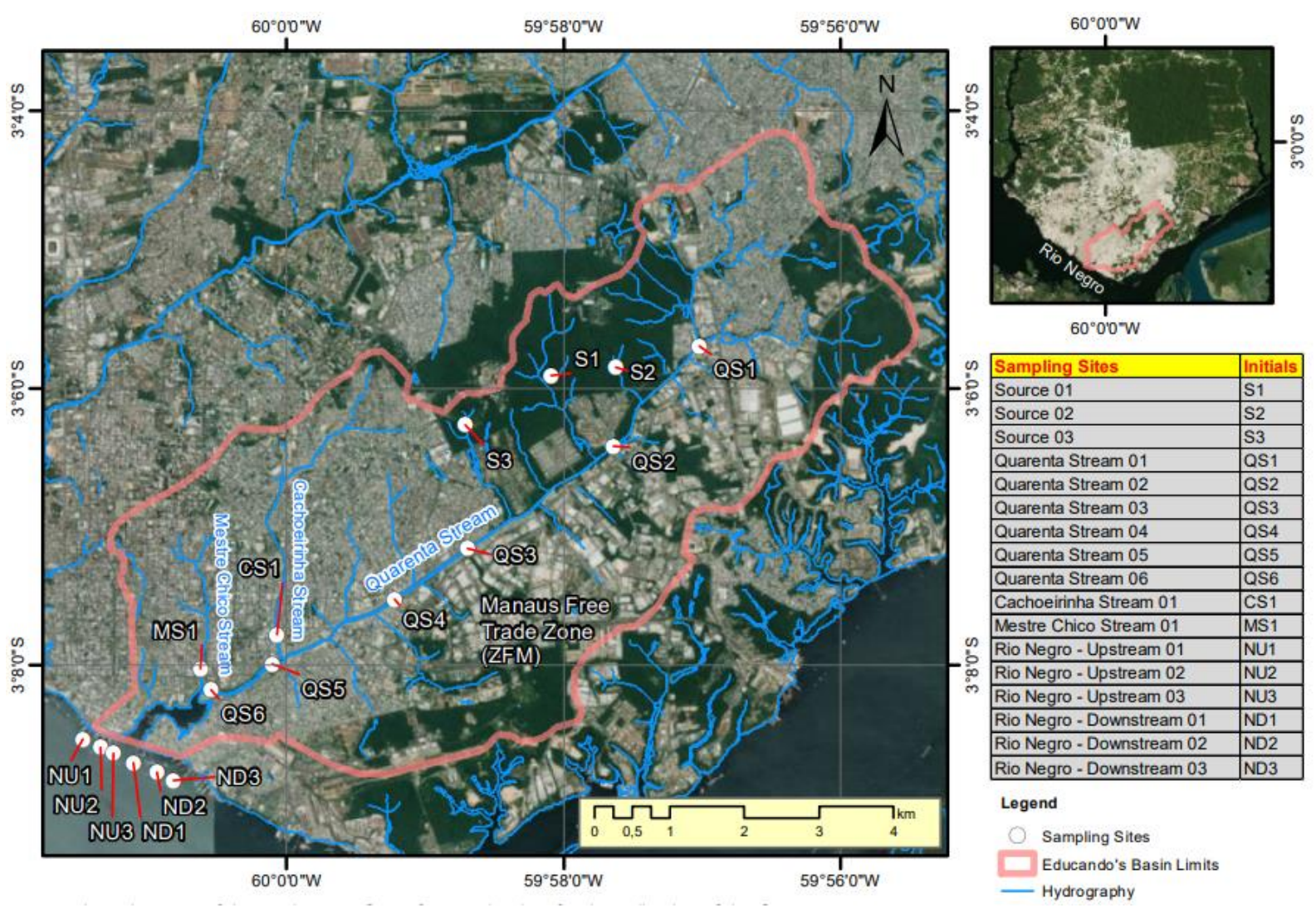

Source - Geological Survey of Brazil (CPRM-SGB), 2020.

\section{RESULTS AND DISCUSSION}

For each collection spot, eighteen parameters were analyzed: five physical and chemical parameters (Electrical Conductivity, Hydrogenionic Potential, Temperature, Turbidity and Total Suspended Solids), five anions (Bicarbonate, Chloride, Sulfate, Nitrate and Fluoride) and eight cations (Iron, Aluminum, Zinc, Nickel, Cadmium, Lead, Chromium and Vanadium). They represent important indicators for the level of degradation over water quality of Educandos and Manaus' shoreline.

Each parameter shall demonstrate the data of all the spots in both hydrological periods considered, comparing the results obtained with those detected by previous studies of natural waters and the same streams analyzed by us. Finally, we shall proceed a multivariate statistical analysis (Cluster Analysis and Principal Component Analysis), observing grouping cases between variables and sites, the influence of sewage and industrial anthropic emission and oscillation among the collection spots at Rio Negro's shoreline.

\section{Electrical Conductivity, pH, Temperature and Bicarbonates}

Natural waters near Educandos present low conductivities, usually lower than $20 \mu \mathrm{S} \mathrm{cm} \mathrm{cm}^{-1}$ at sources

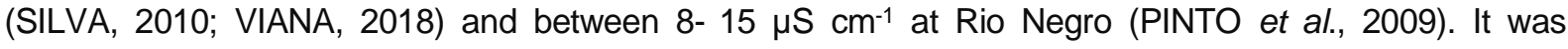
observed conductivities from 9.3 to $19.4 \mu \mathrm{S} \mathrm{cm}^{-1}$ on the samples collected at the sources and from 10.3 to $13.1 \mu \mathrm{S} \mathrm{cm} \mathrm{cm}^{-1}$ on those collected at Rio Negro. On the other hand, the conductivity levels found on the samples collected at the streams were significantly higher, oscillating from 98.0 to $401.3 \mu \mathrm{S} \mathrm{cm}^{-1}$ (Fig. 2a), showing a tremendous alteration caused by anthropic activity. The highest levels were discovered on streams located on places with more sewage emitted (COSTA et al., 2016), that is, Mestre Chico (MS1) and Cachoeirinha (CS1) streams. Our data shows higher levels than those obtained years ago by SILVA;

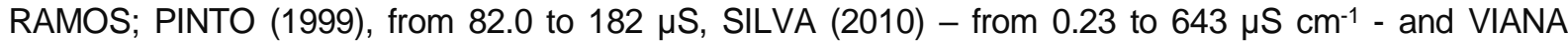
(2018) - from 113.9 to $329.0 \mu \mathrm{S} \mathrm{cm} \mathrm{c}^{-1}$. 
Figure 2 - Average values for E.C. (a), pH (b), Temperature (c) e $\mathrm{HCO}_{3}{ }^{-}$(d) on Wet and Dry Seasons.

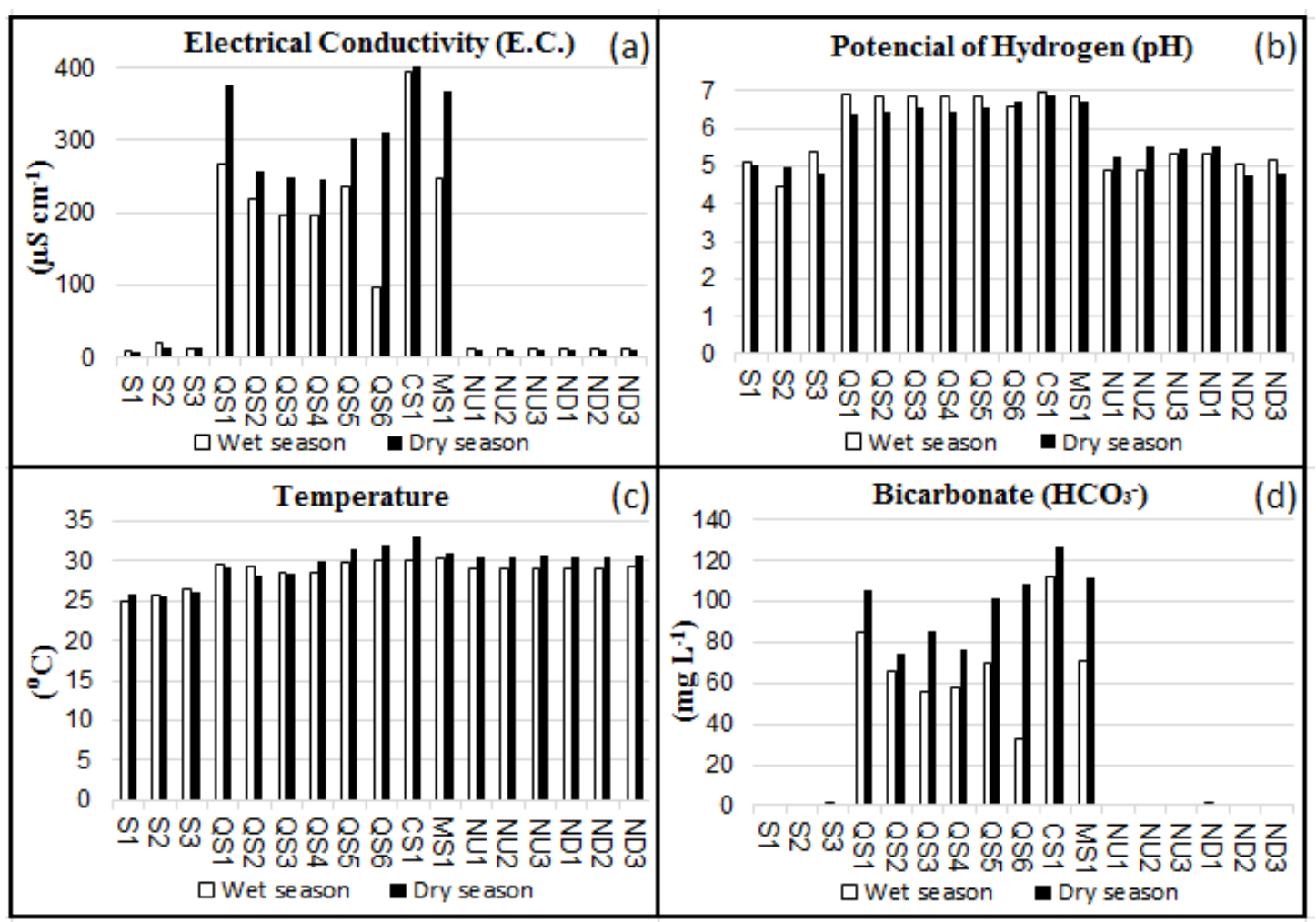

The $\mathrm{pH}$ of Rio Negro and Educando's sources are naturally acid, usually varying between 3.5 and 5.5 (MELO; SILVA; MIRANDA, 2005; PINTO et al., 2009; SILVA, 2010; VIANA, 2018). On this paper, the pH of Rio Negro varied between 4.77 and 5.51 and between 4.43 and 5.38 on the sources, being almost neutral at the streams - from 6.42 to 6.98 (Fig. 2b). The pH measured for urban watercourses were altered by anthropic activity, with higher levels identified at places which were more contaminated by sewage, alkalinizing the water (MELO; SILVA; MIRANDA, 2005; RODRIGUES; SILVA; SILVA, 2009; NORMANDO, 2014). pH shows, as well as E.C., reduction of its percentages in the industrial area (QS2 to QS4). Looking at the retrospect, it is obtained a gradual evolution of its levels, which possibly represents an increase of sewage. For Educandos streams MACHADO and SANTANA (2000) measured pH varying from 6.28 to 7.31, RODRIGUES; SILVA; SILVA (2009) found 6.7 to 7.2, SILVA (2010) from 5.5, to 6.9, NORMANDO (2014) from 6.61 to 6.92, and VIANA (2018) between 6.37 and 7.01. Brazilian National Environmental Counsel, or CONAMA (BRAZIL, 2005), establishes values between 6.0 and 9.0 for "adequate water pH", which means that only the streams, more polluted, would present adequate values by this regulation, once Amazon region's waters are typically more acid than those detected in the rest of the country.

Measured temperatures were found similar for streams (from $28.2^{\circ} \mathrm{C}$ to $33.0^{\circ} \mathrm{C}$ ) and Rio Negro (from 28.9 ${ }^{\circ} \mathrm{C}$ to $30.7^{\circ} \mathrm{C}$ ) (Fig. 2C), with lower values at the sources (from 25.0 to $26.4{ }^{\circ} \mathrm{C}$ ). This is the consequence of a reduced solar incidence on the sources, caused by the presence of plants covering (MELO; SILVA; MIRANDA, 2005). At this basin, temperature is a parameter lowly influenced by anthropogenic emissions, mainly due to local temperature, season of the year, flow rates and depth (COSTA et al., 2016). On dry season, waters showed higher temperatures, probably motivated by higher local temperatures. Observed temperatures were similar to those obtained in past studies, a consequence of a low regional thermic amplitude, with MELO; SILVA; MIRANDA (2005), NORMANDO (2014) and VIANA (2018) observing temperatures between 25 and $28{ }^{\circ} \mathrm{C}$ at the sources and from 28.0 to $33^{\circ} \mathrm{C}$ at the streams.

It was also observed low contents of bicarbonate on Rio Negro's waters and sources, lower than quantification limits $\left(1.5 \mathrm{mg} \mathrm{L}^{-1}\right)$, while the streams values varied between $32.9 \mathrm{mg} \mathrm{L}^{-1}$ and $126.7 \mathrm{mg} \mathrm{L}^{-1}$ (Fig. 2d). This significative difference indicates that, at this basin, the anthropic emissions have altered bicarbonates concentrations, especially considering the expressively low contents observed at the sources. MELO; SILVA; MIRANDA (2005) found bicarbonates concentrations lower than $3.0 \mathrm{mg} \mathrm{L}^{-1}$ at the sources and between 50 and $79 \mathrm{mg} \mathrm{L}^{-1}$ in streams. Higher contents encountered at the streams occurred on the region waste is basically composed by sewage (MS1 and CS1) and lower values were observed on

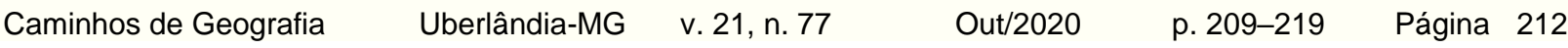


"industrial waste region" (QS2 to QS4). Bicarbonates distribution at the watercourses presented similarities to those identified for $\mathrm{pH}$ and conductivity.

Seasonality seems to alter conductivity and bicarbonates levels (Fig. $2 \mathrm{a}$ and $2 \mathrm{~d}$ ), with higher values occurring on dry season, caused by a decrease of water mass for dilution (MELO; SILVA; MIRANDA, 2005; SILVA, 2010; COSTA et al, 2016). There are also great seasonal alterations at spots QS6 and MS1, near Rio Negro, with really reduced concentrations on wet season, consequence of seasonal variations on the river at those places, diluting the streams.

Spots at Rio Negro show great homogeneity for parameters as $\mathrm{pH}$, E.C., Temperature and $\mathrm{HCO}_{3^{-}}$, without distinction between spots located at the upstream and the downstream of Quarenta stream, indicating it has little influence on Rio Negro's quality on its shoreline. Conductivity, Bicarbonate and pH present slightly higher concentrations at the confluence with Educandos basin (NU3 e ND1), suggesting a punctual contamination on Rio Negro caused by Quarenta stream (PINTO et al, 2009).

\section{Turbidity and Total Suspended Solids}

Sources of Educandos basin and Rio Negro show little suspended material, with turbidity usually inferior to 10 NTU at those environments (COSTA et al., 2016; PASCOALOTO and SOARES, 2016; VIANA, 2018). For this research, it was measured a turbidity level varying from 0.89 to 21.5 NTU for sources, from 3.5 to 8.4 NTU at Rio Negro and from 10.0 to 97.3 NTU at the streams (Fig. 3a).

Figure 3 - Average values for Turbidity (a) and TSS (b) on Wet and Dry seasons.

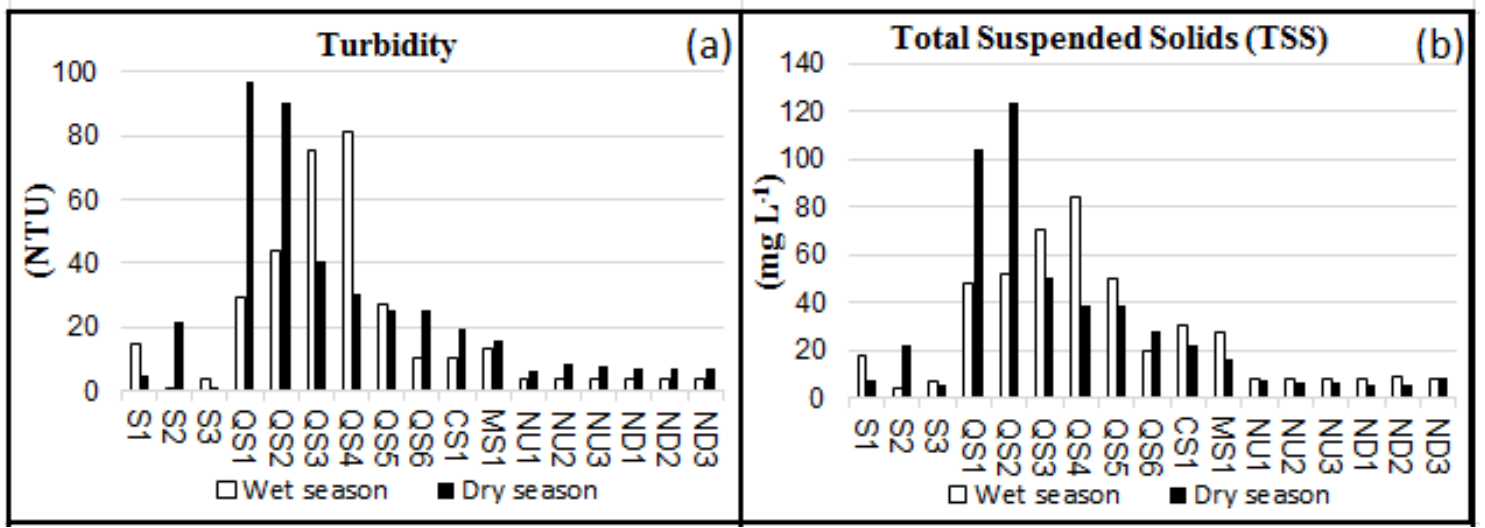

Despite the disparity between streams and other ambiances, turbidity at Educandos basin couples up more with hydrodynamic characteristics than with anthropic activities (COSTA et al., 2016). Comparison along with past studies demonstrate a great fluctuation of this parameters at the streams, with NORMANDO (2014) observing contents from 12.8 to 86.0 NTU, COSTA et al. (2016) from 4.2 to 274.5 FTU, PASCOALOTO and SOARES (2016) found an average value of 12.6 FTU and VIANA (2018) of 37 to 554 NTU. In its Resolution 357, CONAMA (BRAZIL, 2005) establishes a limit of 100 NTU, which means spots QS1 and QS2 of dry season are classified as "inadequate" (Class 2 ) by its terms.

Total suspended solids oscillated from 4.6 to $22.2 \mathrm{mg} \mathrm{L}^{-1}$ at the sources, from 5.9 to $8.1 \mathrm{mg} \mathrm{L}^{-1}$ at Rio Negro, while contents measured at the streams were higher - between 16.8 and $\mathrm{mg} \mathrm{L}^{-1}$ (Fig. 3b). Its tendencies were very similar to those detected for turbidity, by both representing suspended particles quantity (HERNGREN; GOONETILLEKE; AYOKO, 2005). Therefore, this parameter doesn't represent the anthropogenic activity at the streams, despite presenting higher levels there.

The spots which have presented higher levels of turbidity and suspended solids concentration are at initial and intermediate regions of Quarenta stream, where industrial waste emission predominates. At the mouth of Cachoeirinha and Mestre Chico streams, it was detected a quite low level of contents, close to those expected for natural waters. Seasonal variation causes great hydrodynamic changes among the spots located at the sources. Data obtained from QS6 spot shows that, on wet season, the stream's fluid flow is drastically altered by Rio Negro, presenting a much higher level and laminar flow, showing less turbidity and suspended solids consequently. 


\section{Anions (chloride, sulfate, nitrate e fluoride)}

Among analyzed anions, the concentration detected follows the sub sequential order (according to the predominance): $\left[\mathrm{HCO}_{3}^{-}\right]>\left[\mathrm{Cl}^{-}\right]>\left[\mathrm{SO}_{4}{ }^{-2}\right]>\left[\mathrm{NO}_{3}^{-}\right]>\left[\mathrm{F}^{-}\right]$.

Among the four types of anions analyzed by chromatography, chlorides were the most abundant at the streams - between 7.1 and $42.5 \mathrm{mg} \mathrm{L}^{-1}$; average value $19.9 \mathrm{mg} \mathrm{L}^{-1}$ (Fig. 4a) -, while the quantity identified at the sources and at Rio Negro was between 0.35 a $0.89 \mathrm{mg} \mathrm{L}^{-1}$. Chloride distribution seems to represent anthropogenic influence at this basin appropriately, once content levels were found higher on anthropized environments. Among availed streams, chloride levels are higher at regions with more emission of sewage (CS1 and MS1), and lower at regions located near ZFM (QS2 to QS4). Obtained contents are considered "adequate" according to CONAMA (BRAZIL, 2005) legislation, which establishes $250 \mathrm{mg} \mathrm{L}^{-1}$ as limit.

Figure 4 - Average values for $\mathrm{Cl}-(\mathrm{a}), \mathrm{SO}_{4}^{2-}(\mathrm{b}), \mathrm{F}^{-}(\mathrm{c})$ e $\mathrm{NO}_{3}^{-}$(d) on both wet and dry seasons.

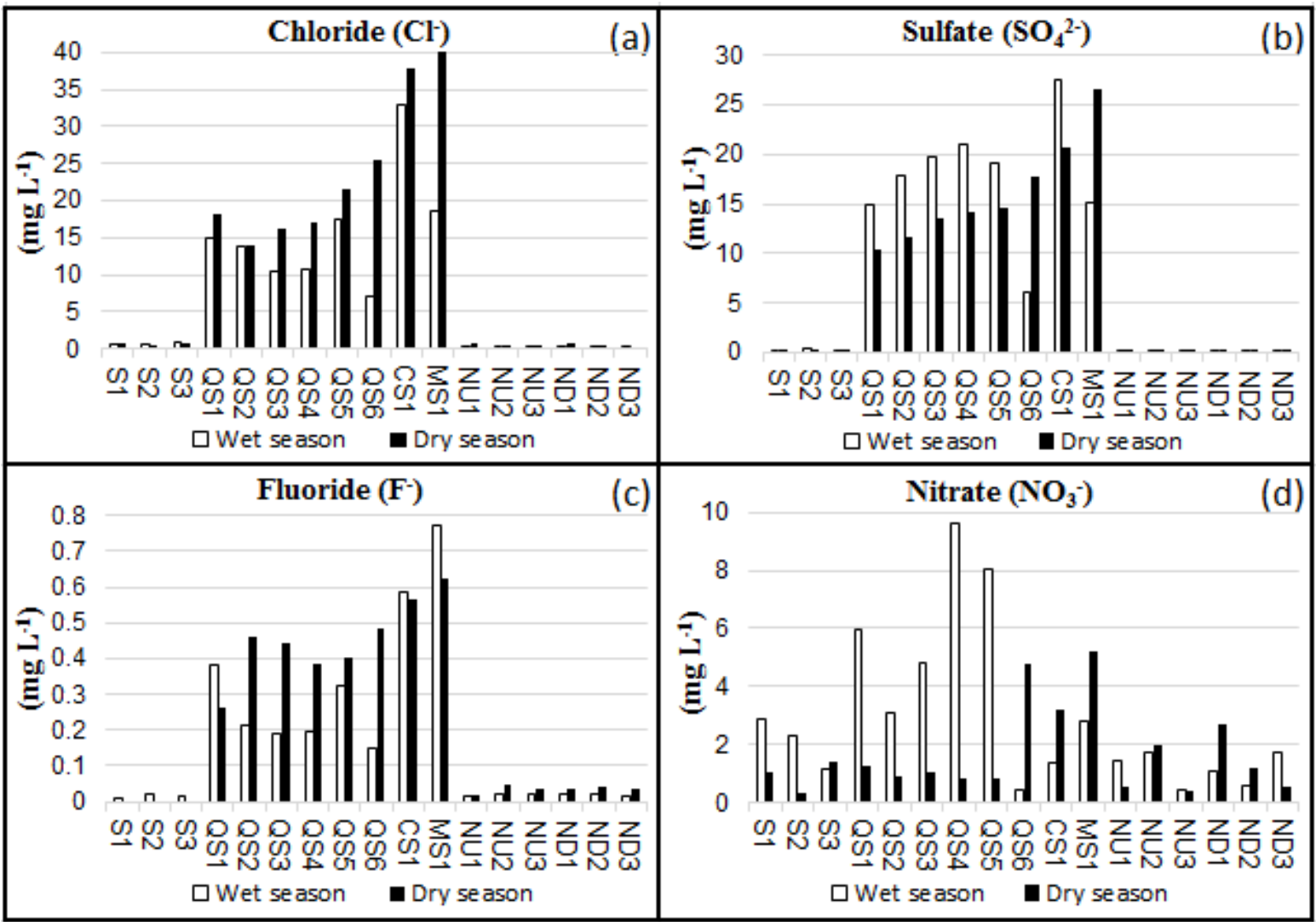

Sulfate concentrations detected at the sources and at Rio Negro were considered low (between 0.14 and $0.45 \mathrm{mg} \mathrm{L}^{-1}$; average value of $0.23 \mathrm{mg} \mathrm{L}^{-1}$ ), compared to the levels found at the streams (from 6.0 to 26.6 $\mathrm{mg} \mathrm{L}^{-1}$; average value of $16.9 \mathrm{mg} \mathrm{L}^{-1}$ ) (Fig. 4b). This great variance among aquatic environments indicates that, at the streams belonging to this basin, sulfates were affected by anthropogenic activity, caused by both sewage and industrial waste (as chemical, pharmaceutical and pulp and paper manufacturing processes). Despite the fact spots MS1 and CS1 have shown the highest sulfate concentrations among streams, it was observed QS3 and QS4 possess similar concentrations, being obtained that, on both seasons, sulfate contents increased along the watercourse near industrial region (QS2 to QS4). It indicates the elevated quantity of sulfates at the streams has been motivated by both sewage and industrial waste emissions. Nonetheless, sulfate levels are considered "adequate" according to the limit values proposed by Resolution 357 regarding Water Potability of CONAMA (BRAZIL, 2005).

Fluorides usually present lower concentrations in environments compared to chlorides, sulfates and nitrates. At Rio Negro and sources, it was detected contents from $>0.01 \mathrm{mg} \mathrm{L}^{-1}$ to $0.04 \mathrm{mg} \mathrm{L}^{-1}$, and from $0.38 \mathrm{mg} \mathrm{L}^{-1}$ to $0.62 \mathrm{mg} \mathrm{L}^{-1}$ (average value $0.17 \mathrm{mg} \mathrm{L}^{-1}$ ) (Fig. 4c). Fluorides typically predominate at places with more emission of sewage (MS1 and (CS1) and present lower content near ZFM. All spots have shown fluoride concentration level below the limit of $1.4 \mathrm{mg} \mathrm{L}^{-1}$ established by CONAMA (BRAZIL, 2005).

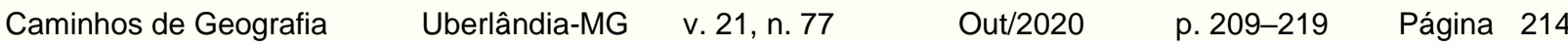


All three anions (chlorides, fluorides and sulfates) have presented higher concentrations motivated by anthropic activity, especially during dry season (Figs. 4a, 4b and 4c). Concentrations found at Rio Negro were considered homogenous among each other and close to those found at the sources. Close values observed between upstreams and downstreams indicates Quarenta stream probably has little influence over Rio Negro's quality, which shows condition consistent with those proper of natural waters (PINTO et al., 2009). There is a noticeable "seasonal difference" of the concentrations detected at the spots located at streams near Rio Negro, especially QS6 and MS1. These places present contaminant concentrations much lower on wet season, due to Rio Negro's seasonal level fluctuations, barring and diluting the streams during their floods.

Spots which have shown higher contents of the three anions (chlorides, fluorides and sulfates) are located at the mouths of Cachoeirinha e Mestre Chico streams (MS1 and CS1), in which it is possible to identify higher concentrations of sewage - influencing especially Chloride and Fluoride levels, which were found twice higher than average values obtained for Quarenta stream. Sulfates, however, present significative contribution motivated by industrial waste.

Nitrate levels at Rio Negro and sources have varied between $0.39 \mathrm{mg} \mathrm{L}^{-1}$ and $2.84 \mathrm{mg} \mathrm{L}^{-1}$, lower than those observed at the streams (from $0.81 \mathrm{mg} \mathrm{L}^{-1}$ to $9.63 \mathrm{mg} \mathrm{L}^{-1}$; average value of $3.39 \mathrm{mg} \mathrm{L}^{-1}$ ). It was also observed higher nitrate levels on wet season, which means that, possibly, nitrate observed in watercourses can also be a consequence of lixiviation. Measured contents were lower than those found by Normando (2014) (1.2 to $2.47 \mathrm{mg} \mathrm{L}^{-1}$ ). Obtained values were lower than CONAMA's legislation limits (BRAZIL, 2005)

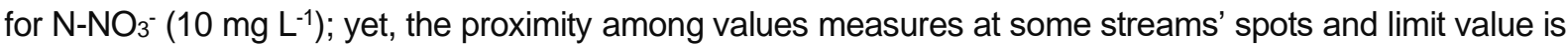
concerning, indicating improvements must be incremented in order to reduce those levels. This parameter showed a less notorious distinction between streams and other environments, being, among all five analyzed anions, the one which less represents Educandos basin anthropization level (COSTA et al., 2016). Its distribution changed according to seasonality: on wet season, nitrate levels were higher at the industrial region (QS3 and QS4), and, on dry season, it was more abundant at "sewage sectors" (CS1 and MS1). It was the only anion to show higher average concentration on wet season.

\section{Cations (iron, aluminum, zinc, nickel, cadmium, lead, chromium and vanadium)}

Among all cations analyzed at this paper, it is noticed a predominance of $\left[\mathrm{Fe}^{2+}\right]>\left[\mathrm{Al}^{3+}\right]>\left[\mathrm{Zn}^{2+}\right]>\left[\mathrm{Ni}^{2+}\right]>\left[\mathrm{Cd}^{2+}\right]$, $\left[\mathrm{Pb}^{2+}\right],\left[\mathrm{Cr}^{3+}\right],\left[\mathrm{Cu}^{2+}\right]$ e $\left[\mathrm{V}^{+}\right]$.

It wasn't possible to quantify the concentrations of cations $\mathrm{Pb}^{2+}, \mathrm{V}^{+}, \mathrm{Cr}^{3+} \mathrm{e} \mathrm{Cu}^{2+}$ by ICP-OES at any place. $\mathrm{Pb}^{2+}$ and $\mathrm{V}^{+}$have presented concentration levels of less than $0.005 \mathrm{mg} \mathrm{L}^{-1}$ at all spots and less than 0.01 $\mathrm{mg} \mathrm{L}^{-1}$ for $\mathrm{Cr}^{3+}$ and $\mathrm{Cu}^{2+}$. CONAMA's Resolution (BRAZIL, 2005) establishes a limit (for freshwater) of 0.01 $\mathrm{mg} \mathrm{L}^{-1}$ for $\mathrm{Pb}^{2+}, 0.1 \mathrm{mg} \mathrm{L}^{-1}$ for $\mathrm{V}^{+}, 0.05 \mathrm{mg} \mathrm{L}^{-1}$ for $\mathrm{Cr}^{3+}$ and $0.009 \mathrm{mg} \mathrm{L}^{-1}$ for $\mathrm{Cu}^{2+}$. Thus, these metals are classified as "adequate" according to the legally established conditions.

Among iron concentrations in waters, it was observed average values of, respectively, $0.18 \mathrm{mg} \mathrm{L}^{-1}$ and 0.20 $\mathrm{mg} \mathrm{L}^{-1}$ at the sources and at Rio Negro; at the streams, it was observed an average concentration value of $0.46 \mathrm{mg} \mathrm{L}^{-1}$, with content values oscillating between $0.29 \mathrm{mg} \mathrm{L}^{-1}$ to $0.80 \mathrm{mg} \mathrm{L}^{-1}$ (Fig. 5a). Having been detected in a considerably higher quantity at the streams, it is possible Iron found in this basin's waters has its values altered by anthropic activity. Iron has predominated at the streams at both industrial (QS2 to QS4) and sewage sectors (MS1 and CS1). Several spots have shown iron levels above limits accepted by CONAMA (BRAZIL, 2005), of $0.3 \mathrm{mg} \mathrm{L}^{-1}$, mainly on dry season. Contents obtained in this research were lower than those observed by Geissler (2003) - with maximum concentrations of $21.6 \mathrm{mg} \mathrm{L}^{-1}$-, MACHADO and SANTANA (2000) - $29.9 \mathrm{mg} \mathrm{L}^{-1}$-, and COSTA et al. (2016) - maximum concentrations of $0.2 \mathrm{mg} \mathrm{L}^{-1}$.

Measured average concentrations of Aluminum in waters were of $0.14 \mathrm{mg} \mathrm{L}^{-1}$ at Rio Negro, $0.09 \mathrm{mg} \mathrm{L}^{-1}$ at the sources and $0.18 \mathrm{mg} \mathrm{L}^{-1}$ at streams, with fluctuation from $0.07 \mathrm{mg} \mathrm{L}^{-1}$ to $0.32 \mathrm{mg} \mathrm{L}^{-1}$ for this ambience (Fig. 5b). Despite little difference among environments, it is probable anthropic activity has changed aluminum concentration at the streams - predominating in spots located at industrial sector (QS2 to QS4). Spots at the mouths of Cachoeirinha and Mestre Chico streams have shown aluminum contents lower than those found at Rio Negro, probably due to their waters' $\mathrm{pH}$, more elevated, which facilitates this metal precipitation. CONAMA (BRAZIL, 2005) designates a maximum limit of $0.1 \mathrm{mg} \mathrm{L}^{-1}$ of aluminum in waters, which means almost all spots at the streams are classified as "inadequate".

$\begin{array}{lllll}\text { Caminhos de Geografia } & \text { Uberlândia-MG } & \text { v. 21, n. } 77 & \text { Out/2020 } & \text { p. 209-219 Página } 215\end{array}$


Figure 5 - Average values of $\mathrm{Fe}^{2+(a)}, \mathrm{Al}^{3+}(\mathrm{b}), \mathrm{Zn}^{2+}(\mathrm{c})$ e $\mathrm{Ni}^{2+}(\mathrm{d})$ for both wet and dry seasons.

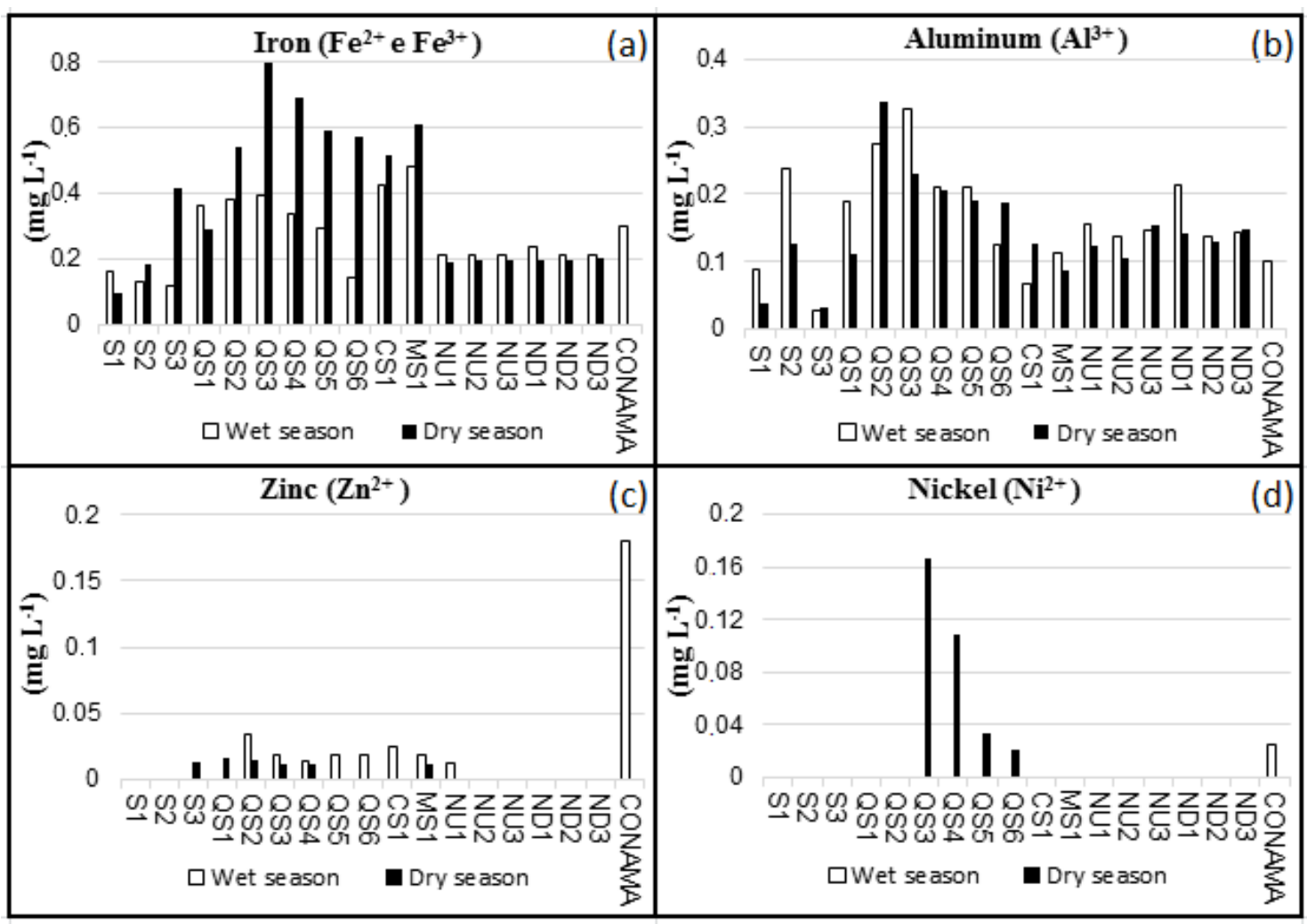

In relation to zinc levels, it was observed maximum concentration of $0.033 \mathrm{mg} \mathrm{L}^{-1}$ at streams, $0.013 \mathrm{mg} \mathrm{L}^{-1}$ at sources and $0.011 \mathrm{mg} \mathrm{L}^{-1}$ at Rio Negro (Fig. 5c). Almost all Zinc quantifying values $\left(\left[\mathrm{Zn}^{2+}\right]>0.01 \mathrm{mg} \mathrm{L}^{-1}\right)$ were detected at the streams, confirming anthropic activity influence over altered parametric results obtained there. In this study, we couldn't verify which emission source (sewage or industrial waste) predominates at the streams. Observed Zinc contents were lower than those obtained by Geissler (2003) maximum value of $14.68 \mathrm{mg} \mathrm{L}^{-1}$-, SAMPAIO and SANTANA (2000) - $19.6 \mathrm{mg} \mathrm{L}^{-1}$-, and MACHADO and SANTANA (2000) - $15.07 \mathrm{mg} \mathrm{L}^{-1}$. Resolution 357 (BRAZIL, 2005) establishes as "adequate" zinc levels inferior or equal to $0.18 \mathrm{mg} \mathrm{L}^{-1}$, a limit above all obtained concentrations.

Among Nickel concentrations in water, quantifying Nickel levels $\left(\left[\mathrm{Ni}^{2+}\right]>0.01 \mathrm{mg} \mathrm{L}^{-1}\right)$ were detected only in Quarenta stream, mainly at industrial sector (QS2 to QS4), with maximum value of $0.16 \mathrm{mg} \mathrm{L}^{-1}$ (Fig. $5 \mathrm{~d}$ ). Found content values were lower than maximum values obtained by SILVA (2010) $-8.3 \mathrm{mg} \mathrm{L}^{-1}$. Among all seven metals analyzed in this paper, Nickel got third place in quantifying values, being noticeable in all spots among the streams in, at least, one of seasonal periods. Spots QS3, QS4 and QS5, on dry season, have shown levels that surpass greatly the limit established by CONAMA's Resolution 357 (BRAZIL, 2005), of $0.025 \mathrm{mg} \mathrm{L}^{-1}$ for $\mathrm{Ni}^{2+}$ in freshwater, indicating a remarkable punctual contamination caused by industrial waste on streams' waters.

In general, all measured metals predominate in watercourses located near industrial regions, due to the several applications these metals have in factory processes. They are typically associated to anthropogenic activity, once they are rarely found in great quantity in waters (at least naturally). Measured potentially toxic metals levels were much lower than those observed by SAMPAIO and SANTANA (2000), MACHADO and SANTANA (2000), SILVA (2010), COSTA et al. (2016) and VIANA (2018), representing a possible decrease on industrial waste emission in the last years.

\section{Availing anthropogenic influence by relation with variables and studied places}

Multivariate analysis was realized for all seventeen collection spots, evolving 14 parameters $(\mathrm{pH}$, Conductivity, Temperature, Turbidity, Suspended Solids, Bicarbonates, Chlorides, Sulfates, Fluorides, Nitrates, Iron, Aluminum, Zinc and Nickel) and seeking to observe relations constructed among these variables and the studied places to confirm existing anthropogenic influence. Tests were separated by

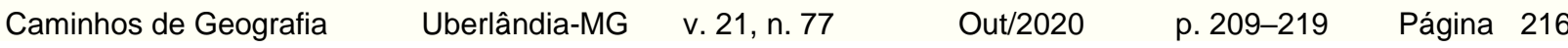


hydrological season, looking for visualizing seasonal differences. All data was normalized. Graphics were obtained by software Originlab. Principal Components Analysis (PCA) and Cluster Analysis (HCA) were the techniques utilized here (Fig. 6). Principal Components Analysis (PCA) seeks to reduce data dimensionality by linear combinations, exporting Biplot graphics (Scores x Loadings), while Cluster Analysis (HCA) visualizes the grouping among the variables. It was chosen Euclidean distance.

Figure 6 - Principal components analysis and cluster Analysis for wet (a)(c) and dry season(b)(d).

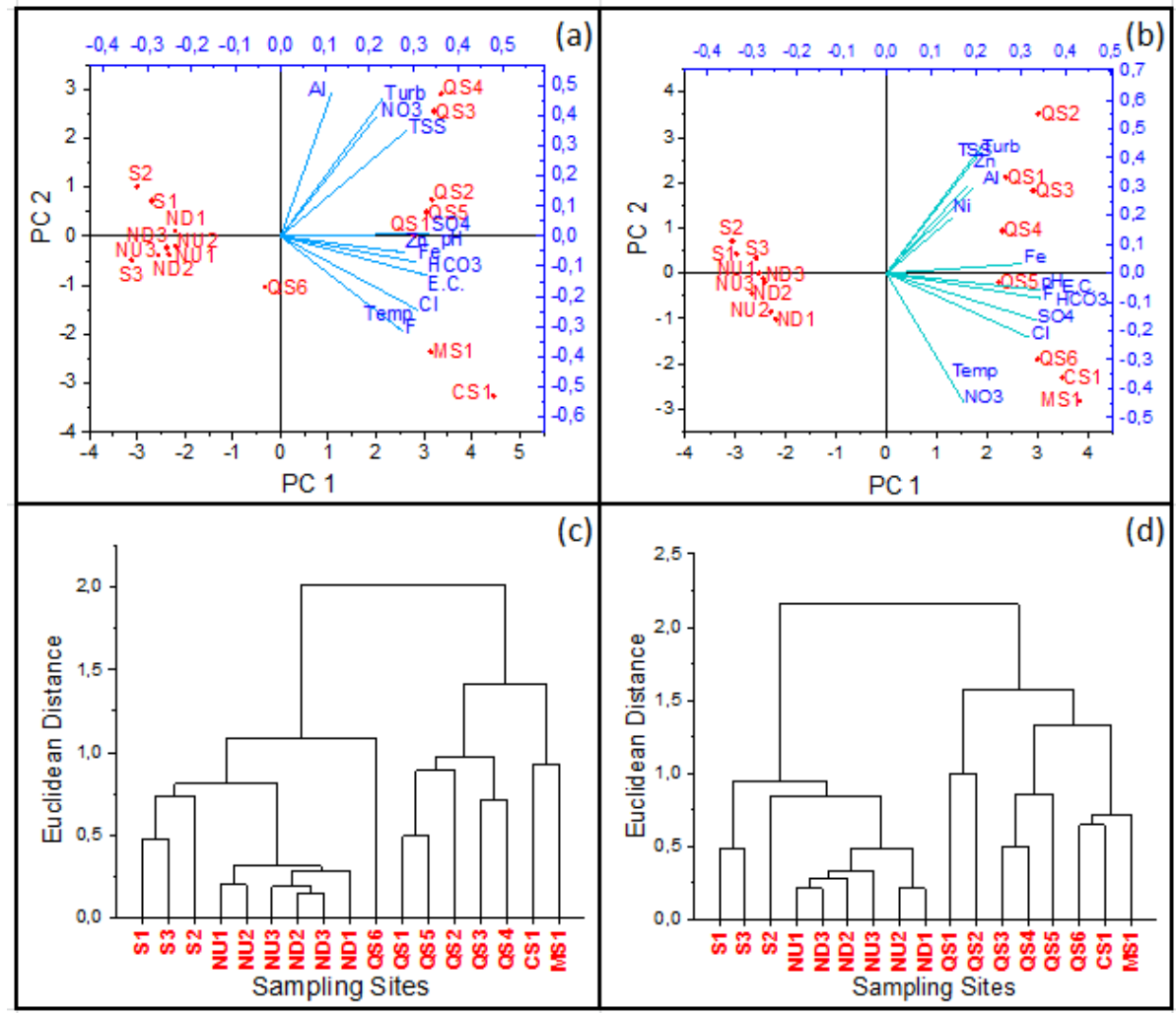

PC1 x PC2 represents 72,9\% of total variance on wet season (Fig. 6a) and 66.2 on dry season (Fig. 6b), with similar distribution on both seasons.

PC1 segregates anthropized environments and higher parameters at the streams, with little difference between Rio Negro and sources. Differences cannot be visualized among Rio Negro's data, that is, between mouth's upstreams (NU1, NU2 and NU3) and downstreams (ND1, ND2 and ND3), indicating Quarenta stream has little influence over Rio Negro. This "streams' segregation" represents how relevant is anthropic activity's influence, significantly altering detected concentrations of several parameters in the streams. PC1 also allows studying which variables represent anthropic contaminations at Educandos basin appropriately, considering $\mathrm{HCO}_{3}-\mathrm{SO}_{4}{ }^{2-}, \mathrm{Cl}^{-}, \mathrm{F}^{-}$, Dissolved Iron, E.C. and $\mathrm{pH}$. Streams' spots with highest PC1 eigenvalues - where most of contaminants predominates - were MS1 and CS1, in the region with more emission of sewage.

PC2, on wet season, has separated by anthropic contamination origin. First quadrant (upright) represents variables and collection spots under predominant influence of industrial waste - or higher at industrial sectors -, which means dissolved Nickel, Iron, Aluminum and Zinc, Total Suspended Solids and Turbidity, greatly present at spots QS2, QS3 and QS4, near Manaus Free Trade Zone. Third quadrant (downright) represents spots or variables related to sewage $-\mathrm{HCO}_{3}{ }^{-}, \mathrm{Cl}, \mathrm{F}$-, E.C. and $\mathrm{pH}-$, markedly high at the mouths of Mestre Chico (MS1) and Cachoeirinha (CS1) streams.

PC2, on dry season, has separated spots QS1 and QS2 from others, due to their high TSS and Turbidity. Segregations are still maintained from spots with higher sewage concentration (MS1 and CS1), at upright quadrant, to those with higher industrial waste concentration (QS2, QS3 and QS4), at downright quadrant.

PC1xPC2 Scores indicate approximated levels of turbidity and suspended solids on both periods, due to the fact they are strongly correlated variables. These parameters' distribution is similar of that identified for

$\begin{array}{lllll}\text { Caminhos de Geografia } & \text { Uberlândia-MG } & \text { v. 21, n. } 77 & \text { Out/2020 } & \text { p. 209-219 Página } 217\end{array}$ 
potentially toxic metals, since, coincidentally, they have predominated at Quarenta's industrial sector (QS2 to QS4). $\mathrm{HCO}_{3}$, E.C. and $\mathrm{pH}$ have presented noticeable proximity at multivariate statistics, as bicarbonates are abundant in environments with $\mathrm{pH}$ value above 6 - increasing local conductivity. These three parameter levels were also close to those found for $\mathrm{F}^{-}$e $\mathrm{Cl}^{-}$, once their predominance is much more attenuated at stream spots MS1 and $\mathrm{CS}_{1} . \mathrm{SO}_{4}{ }^{2-}$ and Iron have been associated to each other, once their distributions indicate that, at Educandos basin, they are consequence of sewage and industrial contamination.

Cluster Analysis (Figs. 6c and 6d) complements the results obtained by PCA. It is visualized a great homogeneity among the results for Rio Negro. Spot QS6 shows variate characteristics according to the season, once, on dry season, its aspects are close to those found at spots MS1 and CS1, and, on wet season, QS6 presents aspects that appear to be intermediate between Rio Negro and a stream. On both seasons, it is detached the proximity between spots MS1 and CS1, located at the mouths of two tributary streams of Educandos basin and of little industrial activity, and between spots QS3 and QS4, located at the intermediate zone of Quarenta stream, near Manaus Free Trade Zone, and of striking contribution of industrial waste in their composition.

\section{CONCLUSIONS}

Most parameters were found altered at anthropized streams; notwithstanding, obtained results have surpassed the limits established by the Resolution n. 357 of CONAMA (BRAZIL, 2005) only for few collection spots and parameters.

Analyzed parameters have demonstrated similar tendencies and distributions on both hydrological periods, with slightly higher contaminant levels being usually detected on dry season. Higher differences among concentrations observed on both hydrological periods occurred at stream spots located closer to Rio Negro (QS6 and MS1). Rio Negro's high-water level on wet season exercises a strong influence at those spots, diluting contaminant levels at the streams.

For this study, it wasn't noticed significative alteration caused by Quarenta stream flow over Rio Negro's quality parameters; however, further research is needed, testing different depths and distances between spots and the shore or a possible metal complexation with dissolved organic matter in Rio Negro's waters.

For almost all parameters, streams have presented more content than their sources, proving the anthropic influence exercised over these watercourses. The predominance of variables among the streams has defined, especially, the origin of contaminant emissions. The regions of Cachoeirinha and Mestre Chico streams' mouths are greatly degraded by sewage, showing the highest contents for $\mathrm{pH}, \mathrm{HCO}_{3}^{-}$, E.C., $\mathrm{Cl}$ and $\mathrm{F}^{-}$. These parameters contents were higher than those observed in researches proceeded in past years, indicating a probable increase in sewage and garbage emissions, even after recent revitalization in the region. In the industrial sectors, metals $\mathrm{Al}^{3+}$ and $\mathrm{Ni}^{2+}$ have predominated, while cations $\mathrm{Pb}^{2+}, \mathrm{Cr}^{3+}, \mathrm{Cu}^{2+}$ and $\mathrm{V}^{+}$weren't quantifiable in the waters, being considered "adequate" according to Brazilian legislation (BRAZIL, 2005) at all spots. Studied metals have shown lower concentrations compared to past studies, which indicates a possible reduction of industrial waste at Quarenta stream in the last years.

\section{REFERENCES}

APHA. Standard methods for the examination of water and wastewater. Washington: American Public Health Association, $23^{\text {rd }}$ ed., 2017.

BRAZIL. Resolução CONAMA 357 de 17 de março de 2005. Brasília, 2005.

COSTA, S. S.; SILVA, M. S. R.; ALVES, A. K.; PINTO, A. G. N.; PASCOALOTO, D.. Análise estatística dos níveis de poluição em bacias hidrográficas de Manaus. In: FERREIRA S.J.F SILVA M.L. PASCOALOTO D. (Org.) Amazônia das Águas qualidade, ecologia e educação ambiental. Manaus: Valer, 2016. p. 161-173.

FILIZOLA, N; GUYOT, J. L. Fluxo de sedimentos em suspensão nos rios da Amazônia. Brazilian Journal of Geology,v. 41, n. 4, p. 566-576, 2011. https://doi.org/10.25249/0375-7536.2011414566576

GEISSLER, R. M. O. Caracterização Geoquímica das águas, Sedimentos de corrente e sedimentos subrecentes da bacia do igarapé do Quarenta, município de Manaus-AM. In: OLIVEIRA J. A; ALECRIM J. D; GASNIER R.J. (Orgs.). Cidade de Manaus: Visões Interdisciplinares. v. 01. Manaus: Edua, 2003.

$\begin{array}{lllll}\text { Caminhos de Geografia } & \text { Uberlândia-MG } & \text { v. 21, n. } 77 & \text { Out/2020 } & \text { p. 209-219 Página } 218\end{array}$ 
GEOCIDADES. Projeto Geo-cidades: Relatório ambiental urbano integrado. Rio de Janeiro: Informe GEO, 2002.

IBGE. Population estimates of municipalities for 2018. In: Instituto Brasileiro de Geografia e Estatística. Available at: <https://www.ibge.gov.br/en/np-statistics/social/population/18448-populationestimates. html?=\&t=0-que-e>. Access: 05 dec. 2018.

HERNGREN L; GOONETILLEKE A; AYOKO A.G. Understanding heavy metal and suspended solids relationships in urban stormwater using simulated rainfall. Journal of Environmental Management, $v$. 76, n. 2, p. 149-158, 2005. https://doi.org/10.1016/j.jenvman.2005.01.013

MACHADO, C. M. D.; SANTANA, G. P. Metais pesados ( $\mathrm{Cu}, \mathrm{Cd}, \mathrm{Zn}, \mathrm{Mn}, \mathrm{Fe}, \mathrm{Pb}$ e $\mathrm{Cr}$ ) em água na região do Distrito Industrial de Manaus-AM. Recife: Abstracts of the XL Congresso Brasileiro de Química, 2000.

MACIEL F.B. Assentamentos precários: o caso de Manaus. In: Caracterização e Tipologia de Assentamentos Precários: estudos de caso brasileiros. Brasília: IPEA, 2016. p. 249-306.

MELO, E.G.F; SILVA, M.S.R.; MIRANDA, S.A.F. 2005. Influência antrópica sobre águas de igarapés na cidade de Manaus - Amazonas. Caminhos de Geografia, v. 5, n.16, p. 40 - 47,2005.

MOLINIER, M.; GUYOT, J. L. L.; DE OLIVEIRA, E.; GUIMARÃES, V. Les regimes hydrologiques de l'Amazone et de sés affluents. In: L'hydrologie tropicale: géoscience et outil pour Le développement. Wallingford: IAHS, 1996. p. 209-222.

NORMANDO M.N. Qualidade da água no Igarapé do Mestre Chico. Dissertação (Mestrado profissional em processos construtivos e Saneamento urbano) - Belém: UFPA: 2014

PASCOALOTO, D. ; SOARES, C. C. Comunidades de algas e qualidade da água em igarapés urbanos de Manaus-AM. In: FERREIRA S.J.F SILVA M.L. PASCOALOTO D. (Org.) Amazônia das Águas qualidade, ecologia e educação ambiental. Manaus: Valer, 2016. p. 91-110.

PINTO,A.G.N; HORB, A.M.C; SILVA, M.S.R; MIRANDA, A.F; PASCOALOTO, D; SANTOS, H. M.C. Efeitos da contribuição antrópica sobre as águas do rio Negro, na cidade de Manaus, estado do Amazonas. Caminhos de Geografia, v. 10, n. 30, p. 26-32, 2009.

RODRIGUES, D. O; SILVA, S. L. R; SILVA, M.S.R. Avaliação ecotoxicológica preliminar das águas das bacias hidrográficas dos rios Tarumã, São Raimundo e Educandos. Acta Amazonica, v.39, n.4, p.935942, 2009. https://doi.org/10.1590/S0044-59672009000400021

SAMPAIO, A. Q. ; SANTANA,G.P. Estudo De Metais Pesados ( $\mathrm{Cu}, \mathrm{Cd}, \mathrm{Zn}, \mathrm{Mn}, \mathrm{Fe}, \mathrm{Pb}$ E Cr) em Água $\mathrm{Na}$ Região Do Distrito Industrial De Manaus (AM). Poços de Caldas: 23a Reunião Anual Da Sociedade Brasileira De Química. 2000.

SILVA M.B. Análise dos níveis de metais potencialmente tóxicos e análise microbiológica nas águas da bacia do Educandos (Manaus - AM). Dissertação (Mestrado em Biotecnologia e Recursos Naturais) Manaus: UEA. 2010.

SILVA, M. S. R; RAMOS J.F; PINTO A.G.N. Metais de transição nos sedimentos de igarapés de ManausAM. Acta Limnológica Brasiliensia, v. 11(2), p89-100, 1999.

VIANA M.C. Estudo de contaminantes em águas de igarapés da zona urbana de Manaus-Amazonas. Dissertação (Mestrado em Química) - Manaus: UFAM. 2018.

Recebido em: 18/02/2020

Aceito para publicação em: 07/08/2020 